\title{
Applying Bruner's Theory using Mini Laboratory on Plane Figures Topic
}

\author{
Zuhri D \\ University of Riau \\ Pekanbaru, Indonesia \\ zuhri.daim@yahoo.com
}

\author{
Sehatta Saragih \\ University of Riau \\ Pekanbaru, Indonesia
}

\begin{abstract}
The aim of this study was to assess the student's mastery comprehensively in recognizing 2-dimensional shapes (triangular and rectangular) by applying the theory of Bruner with using Mini Laboratory. The subject in this study is 78 students in the third grade of elementary school. The study design was a group Pree-test and Post-test. Data is collected by the test, then analyzed by two different average test. The results showed that: (1) there are increases in student mastery of 2dimensional shapes; (2) There are variations on student mastery of 2-dimensional shapes based on shapes design model.
\end{abstract}

\section{Keywords-Bruner Theory, Mini Lab, 2-dimensional shapes}

\section{INTRODUCTION}

Be aware that the management of learning that tends to minimize the role of the students in building their knowledge and lead students to indicate a tendency to memorize the concepts that are given by the teacher. In this situation, the children will lose the sense of learning, and the impact is they are not accustomed to high level's thinking of mathematics. On the one side geometry topic is a vehicle for students to develop critical thinking skills, so it is natural when less emphasis ability to think in learning process causes poor geometry capabilities.

Study results ofSoedjadi[1], Herawati[2], Saragih[3] showed that the geometry unit seems a unit of mathematics that has been difficult category because many encountered misconceptions of elementary school students in looking at the concepts of geometry. This condition, Kerans [4] as a result of learning management is less activity involves students, teachers use strategies that do not match with the intellectual level of the students[1]. Furthermore, Hudojo[5] suggested that the learning activities that are common to the current field are not accommodating to develop students' skills in problem-solving, reasoning, and mathematical communication.

The above statement indicates that the geometry learning management has to give an opportunity for students to build their knowledge through learning activities that support problem-solving ability, reasoning, connecting and mathematical communication terminals. Based on these requirements and is necessary to remain the stage of development of the primary school students are still at the stage of concrete while the characteristics of the object being examined are abstract, so be required teaching strategies that connecting both features, as well as empowering students building they knowledge. One of strategy that is consistent with the ideas of learning is the implementation of the learning theory of Bruner. Bruner argued that each individual at the time recognizing or encounter of experience or the events or objects in the environment to rediscover objects and events in his mind and that is a mental model of events or things that happened. The process consists of three stages namely, stage Enactif, Ikonić and symbolic phase[6].

For implementation perform learning phases Bruner is required well-learning media, in the form of concrete or semiconcrete. The use of the media, especially for elementary students is essentially inseparable from intellectual development is still concrete. Associated with the use of media, Edgar Dale [7] which is famous with Cone of experience suggests that a person's learning experience, $75 \%$ is obtained by the feeling of looking ( eye); $13 \%$ with the senses of hearing (ear); and the remainder through other senses. More said that gaining the level of concrete people get experience (learning) from the level of reality acquired in life.

This statement shows that knowledge is constructed through the use of media is better experienced by students. This means that students immediately use the media in the construction of a learning experience. Learning activities where students are given the opportunity to use this medium can be directly performed by through a mini-lab. In accordance with the above opinion, Bruner states that the best way for someone students to start learning about the concepts, principles or rules in math is constructing concepts, principles or the rules by themselves[5]. Better yet, when students use concrete objects in formulating these ideas. Further said that students learn mathematics should be considered active and it will be fulfilled in a laboratory.

MiniLab is a model of practical activities with simple equipment that can be done in the classroom. Minilab activities can increase student participation in learning because students directly involved in the construction of knowledge through physical activity (demonstration). By manipulation activities (demonstration), students gain a better knowledge and sustainable. Reference [8] Johnson and Rising suggest that people can remember hearing about a fifth, half of his look and three-quarters of his actions.

Pointing stages of learning which showed in the theory of Bruner in building a learning experience and the importance of mini-lab in learning math for elementary student, the researchers try to review comprehensively the impact of learning strategies subject to the student mastery in the topic introduction of shapes 
According to Bruner to learn math is to learn about math concepts and structures of mathematics in the material being examined, as well as looking for connections between concepts and structures of mathematics[6]. Bruner, through his theories, shows that in the process of learning the student should be given chances to manipulate objects or props that are designed specifically and can be tampered with by the students in understanding mathematical concepts.

Jerome Bruner says that learning math is to learn about the concepts and structures of mathematics in the material being studied and to find the relationship between the concepts and structures of mathematics. Bruner described the children progressed through three stages of spiritual development, namely: (1) enactive: At this stage, children learn to manipulate objects; (2) At this stage Ikonić declared that mental activities where children begin, which is a representation of the objects. .In this stage, children do not directly manipulate objects, such as enactive phase, but can be manipulated with the aid of is an image of the object; (3) Symbolic: Phase manipulate symbols to create a direct and nothing to do with the objects anymore.

Bruner also put four Postulate of the learning of mathematics, namely:

The best way for students to learn from a person or principle in mathematics is to build or carry out the preparation as a representation of concepts or principles. Older students are able to have a concept or a principle in understanding the math simply by analyzing a performance by their teachers; However, for most students, especially younger students, the learning process will be better or confirmed if students build their own idea of what they learn. The reason is, if the students can construct their own ideas, they will easier find their own concepts or principles which is contained in the representation, so now they are also easy to remember these things and be able to apply it in the right situations.

According to what is said in notation theory, a mathematical representation of a material can be easily understood by students if the action in the representation of the notation used in accordance with the level of cognitive development of students. The notation is given step by step is a sequence of the most simple to the most difficult. A presentation like this in mathematics is a spiral approach. In a spiral approach, ideas are systematically presented sorted by using notations. In the early stages of this simple notation, followed by the next more complex notation.

In the contrast and the variation, theory showed that a mathematical concept will be more readily understood by the students if the concept is in contrast with other concepts so that the difference between the concept with a different concept becomes apparent. In other hands in this argument is also mentioned that the students understand mathematical concepts are slightly better if the concept was explained using examples that range.

The connectivity theory states that every concept, every customer and every mathematical skill in dealing with concepts, principles and other skills. The relationship between the concepts, principles, and skills that lead to the structure of each branch of mathematics proved. The existence of these relationships also help teachers and other parties (eg curriculum composer, author, etc.) in an effort to develop learning programs for students. In mathematics, the task of the teacher is not only to help students understand the concepts and principles as well as having specific skills, but also help students understand the relationship between the concepts, principles, and these skills. By understanding the relationship between one of the other parts of mathematics, students understand the structure and content of the mathematics become a whole.

The use of the term mini-laboratory (lab-mini) is based on the simplicity instruments (concrete objects) used, and the activities that are carried out in the classroom. It should be noted that in this study, unlike mentioned, the use of props we know so far mini-lab activities. Although the mini-lab activities and the use of props such as the main function to prints and stabilize learned concepts, but different implementation. In the mini-lab activities aimed at students, meaning students individually or in group work demonstrate tools to manipulate learned concepts and principles and draw conclusions express the results of its operations. In this case, the teacher only has to supervise and direct the students to carry out activities in accordance with the instructions in the worksheets and guide students to make a conclusion.

While learning using props that we know, the implementation of activities aimed at the teacher and tools (concrete objects) used only to the extent held by the teacher. That is, the teacher demonstrated (manipulation) to explain the concepts and principles learned while the students only pay attention to the teacher demonstration and explanation. It is clear that in this case no manipulation of concepts or principles.

Further out in this study, the boundary between the laboratory and minilab is only used tools and practical activities. Laboratory activities, as we know it happens in a special room with better tools (modern), while the mini-lab used very simple tools and execute in class. Thus, the activity of students in the mini-lab as activity laboratory activities as usual.

Bell[9] argues that the mathematical approach using the laboratory is a model that can be used by teachers to help students meet the objectives of the cognitive and attitude mathematics. Further stated that laboratory activities are one way to give our students with interesting problems to solve using newly mathematics objects, create a relaxed learning environment where students can learn at their own rate, and help students to be responsible for their own learning. Furthermore, Collins states that "mathematics laboratory and mini-lab offers students the opportunity to investigate and found to work in cooperative groups or work independently[10].

From the above quotes can be concluded that the activities of the mini-laboratories have an important role in learning mathematics. Besides, to encourage students to actively participate in building a more meaningful learning experience, using mini-lab also serves as a bridge to the abstractness of mathematical objects that are easy to teach students to understand in the first place for the primary . 
Additionally, Daniel Lucy[11] in Life Science conclude that the benefits of mini-laboratories are: (1) The minimum equipment, students can do practical activities; (2) Students in facilitating the understanding of the material, because the students are confronted with an object .; (3) to guide students to find their own; (3) train students to think critically; (4) For the students to ask questions, so students have to train more active; (5) To encourage students to explore new concepts; (6) Providing opportunities to learn by studying the use of the scientific method.

Besides the advantages of mini-laboratory methods, there are also some disadvantages: (1) It takes a lot of times, then there are courses unresolved; (2) Requires a lot means so a lot of costs; (3) Not applicable for all courses [8]

Collins[10] showed that, at the disposal of students in learning by using minilab mainly introduced in the beginning because they do not accustom to doing the activities yet that the students get a worksheet to do as a guide to the activities of some to prevent that by means of a mini-laboratory. Student worksheet prepared: (1) treat the question topics; (2) a list of materials needed; (3) steps to make a demonstration; (4) pulling the analysis of the data and conclusions; (5) the questions to help students research and observation. "

\section{METHODS}

Looking at the proposed formulation of the problem, the study included to experimental research that began by the development of teaching materials. The study design used is "One-Group Pree and Post Test Design", described as follows[12]:

$$
\mathrm{O} 1 \mathrm{X} \mathrm{O} 2, \mathrm{O}, .
$$

The subjects are students of the third grade of elementary School in Senapelan District, Pekanbaru City in the school year 2015-2016.The data was collected with the aid of the test, and analyzed by descriptive and inferential statistics.

\section{RESULT AND DISCUSSION}

From the result of data analyze is gotten facts that student's mastery ability to introduce shapes as seen as below :

TABLE I. RECAP OF STUDENT'S MASTERY ABILITY TO INTRODUCE SHAPES DATA

\begin{tabular}{|l|c|c|c|c|c|c|c|c|}
\hline \multirow{2}{*}{ Data Resources } & \multirow{2}{*}{ Before } & \multirow{2}{*}{ After } & \multicolumn{3}{c|}{ Homogeny Test } & \multicolumn{4}{c|}{ Average Test } \\
\cline { 5 - 8 } & & & $\mathrm{F}_{\mathrm{h}}$ & $\mathrm{F}_{\mathrm{t}(0.01)}$ & Kes & $\mathrm{t}_{\mathrm{h}}$ & $\mathrm{t}_{\mathrm{t}(0.05)}$ & Kes \\
\hline $\mathrm{N}$ & 78 & 77 & \multirow{2}{*}{1,65} & 2.04 & $\begin{array}{c}\text { Ho } \\
\text { Accepted }\end{array}$ & 41.3 & 1.64 & Ho Rejected \\
\hline Average & 12,2 & 18,4 & 1,4 & & & & &
\end{tabular}

Based on the facts contained in the table above obtained information that the results of hypothesis testing reject Ho. Furthermore, taking into account the average score of students mastery before and after the action, it can be said that the implementation of guided learning strategy on Bruner's theory by using the Mini-Lab is contributing to the mastery of students in knowing the shapes.

When viewed from the ideal score of maximum and average score that is achieved by students after following the learning it can be stated that there are many students who still have difficulty. Accordingly, it is necessary to describe the mastery of students in every aspect of shape, as contained in the following table:

TABLE II. DESCRIPTION OF AVERAGE SCORE OF STUDENT MASTERY ON RECTANGULAR

\begin{tabular}{|c|c|c|c|c|c|c|c|}
\hline \multicolumn{7}{|c|}{ Kind Of Shape } \\
\hline $\begin{array}{c}\text { Average } \\
\text { Score }\end{array}$ & Square & Rectangle & $\begin{array}{c}\text { Parallelogr } \\
\text { am }\end{array}$ & Rhombus & Trapezoid & Kite & Average \\
\hline Before & 2,2 & 2,1 & 1,5 & 1,3 & 1,2 & 1,9 & 1,82 \\
\hline After & 2,8 & 2,4 & 2,3 & 1,8 & 1,7 & 2,1 & 2.18 \\
\hline
\end{tabular}

TABLE III. DESCRIPTION OF AVERAGE SCORE OF STUDENT MASTERY OF TRIANGLE

\begin{tabular}{|c|c|c|c|c|}
\hline \multicolumn{5}{c|}{ Kind of Shape } \\
\hline $\begin{array}{c}\text { Average } \\
\text { Score }\end{array}$ & $\begin{array}{c}\text { Equilateral } \\
\text { Triangle }\end{array}$ & $\begin{array}{c}\text { Isosceles } \\
\text { Triangle }\end{array}$ & $\begin{array}{c}\text { Right } \\
\text { Triangle }\end{array}$ & Average \\
\hline Before & 2,1 & 1,9 & 1,2 & 1.73 \\
\hline After & 2,6 & 2,2 & 2,1 & 2.30 \\
\hline
\end{tabular}

From the facts that contained in Table 2 and Table 3, it can be stated that the average score of students on both the shape rectangular and triangular are similar. When they are compared with the ideal score, then the average score achievement students after the treatment is quite good although not optimal. Furthermore, for the type of shape, the lowest average student scores lie in the trapezoid and the right triangle.

If analyzed is continued, it can be found that the common model of shape model that is commonly exemplified by the teacher is known better to the students so that the score is better. In contrast, in the form of a model rarely introduced teacher students' mastery is lower with variations in average score different. Table. 4 and Table. 5 describes the shape of a shape model which the average student scores are lowest for each type of shape.

TABLE IV. DESCRIPTION OF RECTANGUlaR SHAPE MODEL WITH LOWEST AVERAGE SCORE

\begin{tabular}{|c|c|c|c|c|c|}
\hline \multicolumn{6}{|c|}{ Jenis Bangu Datar } \\
\hline Square & Rectangel & Paralellogram & Rhombus & Trapezoid & Kite \\
\hline
\end{tabular}




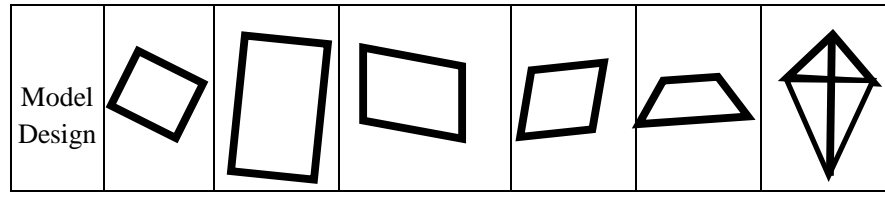

${ }^{\text {d. }}$ Note: Ideal average in each aspect of rectangle is 3

TABLE V. DESCRIPTION OF TRIANGULAR SHAPE MODEL WITH LOWEST AVERAGE SCORE

\begin{tabular}{|c|c|c|c|}
\hline \multicolumn{4}{|c|}{ Kind of Shape } \\
\hline $\begin{array}{c}\text { Average } \\
\text { Score }\end{array}$ & $\begin{array}{c}\text { Equilateral } \\
\text { Triangle }\end{array}$ & $\begin{array}{c}\text { Isosceles } \\
\text { Triangle }\end{array}$ & Right Triangle \\
\hline $\begin{array}{l}\text { Design } \\
\text { Model }\end{array}$ & &
\end{tabular}

e. Note: Ideal average in each aspect of rectangle is 3

From the facts of the picture above, it can be said that the students are less familiar with the shape that is not commonly used as an example by the teacher and is the weak point of the students mastering the shape. Associated with the map of students' weakness in introducing of shape, there are several factors that can be regarded as a trigger, one of which is the application of contradictory propositions that have not been right. The difference of students in viewing at the object of shape because different variations of the form show that student conceptually not understood well about shape's concept designated. The students' perceptions of the example of a shape concept, still focused on the learning experience they already possessed as exemplified by the teacher.

Related to introducing examples of concepts with variations of other forms of concept's examples that students have, it is necessary to do with contrast. In this research, the implementation of this contrasting argument is done by giving instructional media from several types of shape samples in one container, then the students are asked to classify the type.

Taking into the mistakes made by the students, then contrast process should be continued by asking students to draw some examples of shape, either similar or cognate in close proximity to a variety of shapes. For example, students drew an equilateral triangle and an isosceles triangle, or square and rhombus with many variations of shape. With such a process the student can observe directly the changes in the form of a shape example, from the result of his own drawing. This process is seen as stronger in building a student learning experience because students directly demonstrate the illustration of a shape example with a variety of forms. This is parallel with Edgar David's opinion that students will gain a $75 \%$ learning experience of what is they done/demonstrated.

\section{CONCLUSION}

Based on data analyzed, then it can be concluded that :

1. There is an increase in student mastery of shape after following the learning by applying the theory of Bruner using the Mini-Lab
2. There are a variation in student mastery of the shape either the rectangular or triangle

3. The highest increase of student's mastery of shape is the trapezium of rectangles and right triangles for triangles. These two types of shape are the two concepts as the weakest student's mastery.

4. In general, the weakness of students' mastery of the shape is in the form of shape model that is not commonly exemplified by teachers in learning

\section{SugGeStion}

Implementation of a learning strategy by Bruner's theory using Lab-Mini in advanced research is recommended: Students are given the opportunity to draw/trace the types of shape with many variations. This is intended for the learning experience gained at the Enactive stage, and Ikonic is more impregnated and meaningful. The conformity of ideas obtained by students through both stages with the results of student painting will strengthen the learning experience of students. In addition, the sufficient intersection of variations in the model of shapes drawing from the students'drawing will strengthen the students' learning experience about the concept of a shape. Before entering the symbolic stage, the student should give the opportunity to express his argument about the shape that is studied before, so that in the abstract in verbal form students have had ideas about the shape that studied.

\section{REFERENCES}

[1] Soedjadi., R.(1991). Wajah Pendidikan Matematika di Sekolah Dasar Kita (beberapa hasil pengamatan lapangan sebagai perbaikan dimanas depan). Makalah Penataran Penyiapan Calon Guru Penatar Dosen PGSDII Guru Kelas, Jakarta: Tidak diterbitkan

[2] Herawati.,1994. Penguasaan siswa terhadap bangun datar., Tesis., IKIP Surabaya

[3] Saragih, S. (2003). Profil Kemampuan Keruangan Siswa SMP di Kota Pekanbaru. FKIP Universitas Riau Pekanbaru. Hasil Penelitian:Tidak diterbitkan

[4] Kerans, D.S. (1995). Pengajaran Matematika Topik Geometri Pada Beberapa Sekolah di Kota Kupang NTT (Tesis). Pascasarjana IKIP Surabaya. Tidak diterbitkan.

[5] Hudoyo, H. (2002). Representasi Belajar Berbasis Masalah. Jurnal Matematika atau Pembelajarannya. (Edisi Khusus), 427- 432

[6] Hudoyo, H. (1998). Pembelajaran Matematika Menurut Pandangan Konstruktivistik. Makalah disajikan pada Seminar Nasional Upayaupaya Meningkatkan Peran Pendidikan dalam Era Globalisasi. PPS IKIP Malang. Malang, 4 April 1998.

[7] Ruseffendi. Pengantar Kepada Membantu Guru Mengembangkan Kompetensinya dalam Pengajaran Matematika. Bandung: Tarsito. 2006

[8] Bell, F.H. Teaching and Learning Mathematics (In Secondary School). United States of America: Win C. Brown Company. 1978

[9] Collins, William, et al. Mathematics: Applications and Connections. New York: McGraw-Hill. 1995

[10] Daniel, Lucy et al.Life Sience, New York : McGraw-Hill. 1995

[11] Lundgre, Linda. 1994. Cooperative Learning in the Science Classroom Ohio: Glencoe

[12] Tuckman, Bruce W. 1978. Conducting Education Research. San Diego: Harcourt Brace Jovanovich. 